\title{
ANALISIS TERHADAP PERUBAHAN KETENTUAN PENGUPAHAN DI INDONESIA MELALUI TEORI MASLAHAH MURSALAH
}

\author{
Robiatul Adawiyah \\ Fakultas Syariah UIN Maulana Malik Ibrahim Malang \\ Email: Robiatul2468@gmail.com
}

\section{Abstract}

The problem of PP No. 78 year 2015 that causes the action unions which regard that PP is more side to entrepreneur and has been contradictory with labour law. To answer that problem is know the fee changes based on the PP No. 78 year 2015 if reviewed based on principle of the labour law and perspective of Maslahah Mursalah theory to see it. This research uses the research method yuridis normative. The result is fee changes based on the PP No. 78 year 2015 is section 43 article (5) about component of observation KHL that is done every 5 years which before in PP No. 8 year 1981 is done every 1 year. Maslahah Mursalah Ath-Thufi theory see that it is to welfare between workers, entrepreneur, and government. Concluding is provision fee in PP No. 78 year 2015 not contradict with the principle of the labour law and Maslahah Mursalah Ath-Thufi theory see that it as the from of general welfare.

Permasalahan dalam PP No. 78 Tahun 2015 disebabkan aksi serikat kerja yang merasa PP berpihak pada pengusaha dan bertentangan dengan UU Ketenagakerjaan. Untuk menjawab masalah tersebut, harus diketahui perubahan ketentuan pengupahan dalam PP berdasarkan prinsip hukum ketenagakerjaan, serta menganalisanya berdasarkan perspektif Maslahah Mursalah Ath-Thufi. Hasilnya adalah, perubahan ketentuan dalam PP ialah pasal 43 ayat (5) tentang KHL yang ditinjau 5 tabun sekali, yang dalam PP No. 8 Tabun 1981 diatur 1 tahun sekali. Maslahah Mursalab Ath-Thufi menganggap perubahan tersebut sebagai wujud kemaslahatan pekerja, pengusaha dan pemerintah. Hasil akhir adalah bahwa perubahan dalam PP baru tidak bertentangan dengan prinsip hukum ketenagakerjaan yang semata-mata bertujuan untuk kemaslahatan umum.

Keywords: wages, labour, maslahah mursalah 


\section{Pendahuluan}

Pembahasan mengenai pengupahan bagi pekerja selalu menjadi topik aktual. Meskipun sudah terdapat regulasi tentang pengupahan sebut saja UU No 13 Tahun 2003, Permenaker Nomor 17 Tahun 2005 tentang Komponen dan Pelaksanaan Tahapan Pencapaian KHL sebagaimana telah diubah dengan Permenaker Nomor 13 Tahun 2012. Namun permasalahan pengupahan bagi pekerja tetap saja muncul hingga saat ini. Permasalahan pengupahan di Indonesia dewasa ini dipelopori oleh demo organisasi Koalisi Anti Utang-Gerakan Buruh Indonesia di depan Istana Kepresidenan. Demo ini bermaksud menuntut Presiden Joko Widodo agar mencabut PP Nomor 78 Tahun 2015 tentang Pengupahan. Mereka berpendapat bahwa formulasi kenaikan upah minimal berdasarkan inflasi dan pertumbuhan ekonomi telah melanggar UU Nomor 13 Tahun 2003. ${ }^{1}$ Selain itu, menurut mereka PP Nomor 78 Tahun 2015 lebih berpihak pada kepentingan pengusaha. PP Nomor 78 Tahun 2015 juga dianggap mengabaikan harga kebutuhan pokok setiap tahunnya yang menjadi patokan KHL. ${ }^{2}$ Sedangkan di sisi lain, Menteri Ketenagakerjaan Hanif Dhakiri menyatakan bahwa PP tersebut harus dipatuhi karena telah diregulasi dengan melibatkan berbagai pihak dan dibuat seadil mungkin. Pada dasarnya PP Nomor 78 Tahun 2015 telah melindungi buruh agar tidak di PHK, memperbanyak lapangan kerja. Membuat perencanaan usaha dengan baik karena kenaikan upah memiliki formulasi yang jelas. ${ }^{3}$

Hal yang menjadi permasalahan adalah adanya pro kontra antara pemerintah dan masyarakat, hal ini disebabkan kepentingan masing-masing pihak. Berdasarkan konsep Islam, PP merupakan manifestasi maslahah mursalah, karena lahir dari hasil ijtihad untuk melahirkan hukum baru dalam menyelesaikan permasalahan yang sifatnya kekinian. Mashlahah mursalah adalah kemashlahatan yang tidak mempunyai dasar dalil, tetapi juga tidak ada pembatalnya. ${ }^{4}$

Berdasarkan permasalahan di atas, maka fokus pembahasan adalah: (1) Perubahan ketentuan pengupahan dalam PP Nomor 78 Tahun 2015 jika ditinjau berdasarkan prinsip hukum ketenagakerjaan dalam UU Nomor 13 Tahun 2003, dan (2) Perspektif teori Maslahah Mursalah terhadap perubahan ketentuan pengupahan dalam PP Nomor 78 Tahun 2015.

Konsep tentang Pengupahan

1 Gempur M Surya, Ribuan Buruh Akan Bergerak dari Patung Kuda Menuju Istana, (http://news.liputan6. com/read/2386192/. Diakses 22 Januari 2016).

2 Said Iqbal, Selamatkan Upah Buruh Indonesia, (http://www.kompasiana.com/ diakses pada tanggal. Diakses Januari 2016).

3 Angling Adhitya Purbaya, Pro Kontra PP Pengupahan, Menteri Hanif: Merasa Indonesia, Ikuti PP, (http:// news.detik.com/ diakses pada tanggal Diakses 22 Januari 2016).

4 Amir Syarifuddin, Ushul Fiqh Jilid 2, (Jakarta: Prenada Media Group, 2011), h. 356. 
Upah merupakan salah satu unsur yang terkandung dalam sebuah hubungan kerja.Hal ini dasarkan kepada pengertian dari hubungan kerja itu sendiri.Hubungan kerja yaitu hubungan antara buruh dan majikan, terjadi setelah diadakan perjanjian oleh buruh dengan majikan, di mana buruh menyatakan kesanggupannya untuk bekerja pada majikan dengan menerima upah sedangkan majikan menyatakan kesanggupannya untuk mempekerjakan buruh dengan membayar upah. ${ }^{5}$ Pasal 1 angka 3 Undang-undang Nomor 13 Tahun 2003 tentang Ketenagakerjaan menjelaskan bahwa "pekerja adalah setiap orang yang bekerja dengan menerima upah atau imbalan dalam bentuk lain. Komponen upah merupakan segala bentuk pemberian yang dinyatakan dalam bentuk uang dari pengusaha kepada pekerja. Dalam hal ini terdapat beberapa komponen yang dapat dinyatakan sebagai upah pekerja. Komponen upah terdiri dari upah pokok dan tunjangan tetap, besarnya upah pokok sedikit-dikitnya 75\% (tujuh puluh lima perseratus) dari jumlah upah pokok dan tunjangan tetap. ${ }^{6}$

Ketentuan pengupahan juga diatur dalam hukum Islam. Representatif kegiatan muamalah ini adalah akad ijarâh. Dalam memahami definisi ijarâh, para ulama fiqh memberikan definisi ijarâh dengan makna yang berbeda-beda, yaitu: ${ }^{7}$

(1) Ulama Hanafiyah: ${ }^{8}$

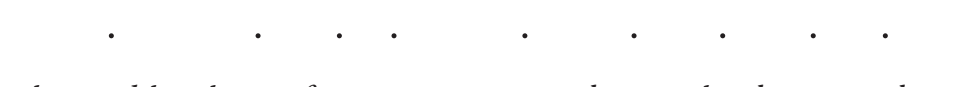

Akad atas suatu kepemilikan kemanfaatan yang mengandung maksud tertentu dari barang yang dipinjamkan dengan pengganti

(2) Ulama Syafi'iyah ${ }^{9}$

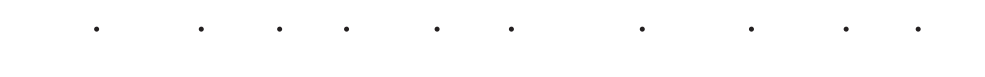
Akad atas suatu kemanfaatan yang mengandung maksud tertentu dan mubah, serta menerima pengganti atau kebolehan dengan pengganti tertentu.

(3) Ulama Malikiyah dan Hanabilah ${ }^{10}$

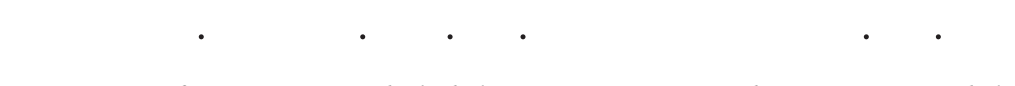

Akad atas suatu kemanfaatan yang mubah dalam waktu tertentu dengan mengambil sesuatu atas suatu barang dengan pengganti tertentu.

\footnotetext{
5 Imam Soepomo, Pengantar Hukum Perburuhan. (Jakarta: Djambatan, 1990), h. 53

6 Pasal 94 UU Ketenagakerjaan

7 Rachmat Syafe'i, Fiqih Muamalah (Bandung: Pustaka Setia, 2001), h. 121

8 Abdul Rahman Al-Jaiziri, Al-Fiqh 'Alâ Madzâhib Al-Arba'ah Juz 3 (Beirut: Daar Al-Kutub AlIlmiyah, 2003), h. 86.

9 Abdul Rahman Al-Jaiziri, Al-Fiqh 'Alâ..., h. 89
}

10 Abdul Rahman Al-Jaiziri, Al-Fiqh 'Alâ..., h. 90 
Berdasarkan beberapa definisi di atas, dapat disimpulkan bahwa yang dimaksud dengan ijarâh adalah transaksi untuk mengambil kemanfaatan yang dibolehkan dari barang yang telah ditentukan dalam jangka waktu yang diketahui atau transaksi jasa yang diketahui dengan alat tukar yang diketahui pula. ${ }^{11}$ Ijârah memiliki dua makna yaitu sewa-menyewa dan upah mengupah. Dalam hakikatnya ijârah adalah menukarkan sesuatu dengan adanya imbalan.Apabila dalam konteks akad upah-mengupah, maka ijârah ialah menjual tenaga atau kekuatan. Jumhur ulama berpendapat bahwa ijârah adalah menjual manfaat atas barang atau mengambil manfaat tenaga manusia berupa jasa. ${ }^{12}$

Rukun dan syarat ijârah menjelaskan bahwa ujroh disyaratkan diketahui jumlahnya oleh kedua belah pihak. Untuk pembayaran ujroh, jika ijârah itu adalah pekerjaan maka kewajiban pembayaran ujrohnya adalah pada waktu berakhirnya pekerjaan. ${ }^{13}$ :

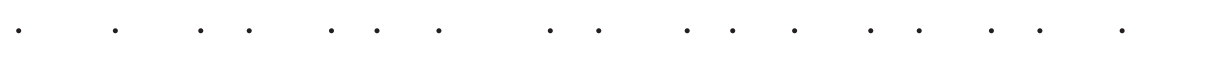

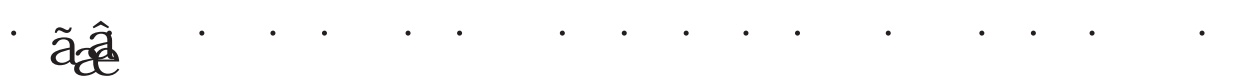

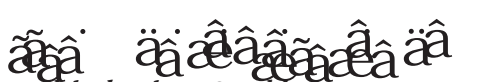

"Dikabarkan Mubammad bin Ali bin Daud berkata dikabarkan Said bin Mansyur berkata dikabarkan Muhammad bin 'Imar Al-Müadzin dari Al-Muqabbari dari Abu Hurairah r.a berkata, Rasulullah SAW bersabda Berikan kepada seorang pekerja upahnya sebelum keringatnya kering."14

Dengan demikian, dapat ditarik kesimpulan bahwa prinsip pengupahan dalam Islam, yaitu: ${ }^{15}$

1) Upah dibayarkan setelah pekerjaan selesai (sebelum keringat pekerja kering)

2) Upah hendaknya dibayar secepatnya sesuai perjanjian

3) Upah diberikan dengan ukuran yang patut

4) Majikan menetapkan upah sebelum buruh bekerja

11 Hendi Suhendi, Fiqih Muamalah (Jakarta: Rajawali Press, 2010), h. 113

12 Rachmat Syafei, Fiqih Muamalah..., h. 121

13 Sohari Sahrani dan Ru'fah Abdullah, Fikih Muamalah (Bogor: Ghalia Indonesia, 2011), h. 172

14 Maktabah Syamilah, Sunan Ibnu Majah Bab Upah-Mengupah, Juz 2, hal. 817

15 Ridwan, Fiqih Perburuan (Yogyakarta: Centra Grafindo, 2007), h. 88 


\section{Prinsip Hukum Ketenagakerjaan dalam UU No. 13 Tahun 2003}

Beberapa prinsip yang terkandung dalam UU Ketenagakerjaan Nomor 13 Tahun 2003 tentang Ketenagakerjaan ialah sebagai berikut:

\section{Prinsip Demokrasi}

Demokrasi adalah sebuah bentuk atau sistem pemerintahan yang segenap rakyat turut serta memerintah dengan perantaraan wakil-wakilnya atau pemerintahan rakyat. Dapat pula berarti sebuah gagasan atau pandangan hidup yang mengutamakan persamaan hak dan kewajiban serta perlakuan yang sama bagi semua warga negara demokrat. ${ }^{16}$

Prinsip demokrasi sendiri meliputi 2 (dua) aspek, yaitu demokrasi antara pemerintah dengan warga negara dan demokrasi antara pengusaha dengan pekerja. Bentuk prinsip demokrasi dalam dunia ketenagakerjaan yang terjalin antara pemerintah dengan warga negara ialah bahwa penegakan demokrasi di tempat kerja diharapkan dapat mendorong partisipasi yang optimal dari seluruh tenaga kerja dan pekerja/buruh Indonesia untuk membangun negara Indonesia yang dicita-citakan. ${ }^{17}$ Adapun prinsip demokrasi antara pengusaha dengan pekerja berarti adanya partisipasi antara pihak pekerja dan pihak pengusaha. Bentuk musyawarah untuk mufakat antara pihak pengusaha dengan pihak pekerja juga telah diatur dalam UU Ketenagakerjaan. Dalam pasal ini disebutkan bahwa bentuk prinsip demokrasi yang terjalin adalah berupa kesepakatan.

Pengaturan pengupahan yang ditetapkan atas kesepakatan antara pengusaha dan pekerja/buruh atau serikat pekerja/serikat buruh tidak boleh lebih rendah dari ketentuan pengupahan yang ditetapkan peraturan perundang-undangan yang berlaku. ${ }^{18}$

\section{Prinsip Perlindungan Tenaga Kerja Sesuai Harkat dan Martabat Kemanusiaan}

Definisi harkat dan martabat dalam prinsip ini ialah perlindungan tenaga kerja sebagai manusia yang memiliki kemuliaan dan harga diri yang sama antar manusia sebagaimana dinyatakan dalam UUD 1945 bahwa "setiap orang berhak atas perlindungan diri pribadi, keluarga, kehormatan, martabat dan harta benda yang di bawah kekuasaannya". ${ }^{19}$

16 Departemen Pendidikan Nasional, Kamus Besar Bahasa Indonesia (Jakarta: Pusat Bahasa, 2008), h. 337

17 Penjelasan Umum UU Ketenagakerjaan

18 Pasal 91 Ayat (1) UU Ketenagakerjaan

19 Pasal 28G UUD 1945 
Beberapa hak-hak dasar pekerja yang dinyatakan dalam UU Ketenagakerjaan yang selanjutnya merupakan hak perlindungan terhadap tenaga kerja sesuai harkat dan martabat kemanusiaan ialah sebagai berikut:

Setiap pekerja/buruh mempunyai hak untuk memperoleh perlindungan atas :

(a) keselamatan dan kesehatan kerja;

(b) moral dan kesusilaan; dan

(c) perlakuan yang sesuai dengan harkat dan martabat manusia serta nilai-nilai agama. ${ }^{20}$

Hak dasar pekerja merupakan hak yang melekat pada diri pekerja yang dibawa sejak lahir dan jika hak tersebut terlepas dari diri pekerja, maka menjadi turun derajat dan harkatnya sebagai manusia. Hak dasar pekerja adalah hak untuk memperoleh pekerjaan yang layak bagi kemanusiaan yang telah diakui keberadaannya dalam UUD 1945 yaitu pada pasal 27. ${ }^{21}$

3. Prinsip Non Diskriminasi

Apabila berbicara tentang hak dasar dalam PP Nomor 78 Tahun 2015, maka hak dasar tersebut ialah mendapat perlindungan upah dan perlakuan yang sama. Dalam UU Ketenagakerjaan bagian menimbang dijelaskan bahwa perlindungan terhadap tenaga kerja dimaksudkan untuk menjamin hak-hak dasar pekerja dan menjamin kesamaan kesempatan serta perlakuan tanpa diskriminasi atas dasar apapun untuk mewujudkan kesejahteraan pekerja dan keluarganya dengan tetap memperhatikan perkembangan kemajuan dunia usaha. Pasal 6 UU Ketenagakerjaan menyatakan bahwa "setiap pekerja/buruh berhak memperoleh perlakuan yang sama tanpa diskriminasi dari pengusaha".22

Maksud dari bunyi pasal di atas ialah bahwa pengusaha harus memberikan hak dan kewajiban kepada pihak pekerja/buruh tanpa membedakan antara jenis kelamin, suku, ras, agama, warna kulit, dan aliran politik. ${ }^{23}$

4. Prinsip No Work No Pay

Prinsip no work no pay yaitu prinsip tidak bekerja maka tidak dibayar. Karena pada dasarnya, upah bagi pihak pekerja diberikan oleh pengusaha apabila terpenuhi unsur-unsur dalam perjanjian kerja salah satunya ialah pekerjaan tertentu atau pelayanan. Namun demikian, prinsip yang diberlakukan dalam dunia ketenagakerjaan ini memiliki pengecualian terhadap beberapa kondisi. ${ }^{24}$ 20 Pasal 86 Ayat (1) UU Ketenagakerjaan

21 Adrian Sutedi, Hukum Perburuan (Jakarta: Sinar Grafika, 2009), h. 16

22 Pasal 6 UU Ketenagakerjaan

23 Penjelasan Pasal 6 UU Ketenagakerjaan

24 Devi Rahayu, Hukum Ketenagakerjaan Teori dan Studi Kasus (Yogyakarta: New Elmatera, 2011), h. 100 
Sebagaimana yang diatur dalam pasal 93 Ayat (1) UU Ketenagakerjaan "upah tidak dibayar apabila pekerja/buruh tidak melakukan pekerjaan.".

Penjelasan pasal di atas bahwa ketentuan tersebut merupakan prinsip yang pada dasarnya berlaku untuk semua pekerja/buruh, kecuali apabila pekerja/ buruh yang bersangkutan tidak dapat melakukan pekerjaan bukan karena kesalahannya.

5. Prinsip Keterpaduan

Keterpaduan sendiri dalam Kamus Besar Bahasa Indonesia berasal dari kata padu yang memiliki arti bersatu, utuh dan kuat. Prinsip keterpaduan berarti prinsip adanya kesatuan dan koordinasi antara pihak pemerintah pada tingkat pusat dan pihak pemerintah pada tingkat daerah. Pada hakikatnya, prinsip keterpaduan ini dilakukan untuk memudahkan pemerintah dalam melakukan pengawasan terhadap pihak pengusaha dan pihak pekerja dalam dunia ketenagakerjaan. "Pembangunan ketenagakerjaan diselenggarakan atas asas keterpaduan dengan melalui koordinasi fungsional lintas sektoral pusat dan daerah. ${ }^{26}$

Maksud dalam pasal ini adalah pembangunan ketenagakerjaan dilaksanakan secara terpadu dalam bentuk kerja sama yang saling mendukung antara pihak pusat dan daerah. ${ }^{27}$ Proses pengawasan yang dilakukan oleh Disnaker daerah selalu ada koordinasi dengan pusat. Pengawas di daerah mendapatkan pelatihan dan pembinaan oleh Kemenakertrans. Bupati/walikota akan melaporkan hasil pengawasan kepada Gubernur, dan selanjutnya Gubernur akan melaporkan Menteri Tenaga Kerja dan Transmigrasi. ${ }^{28}$ Ini merupakan bentuk dari prinsip keterpaduan.

\section{Pengupahan Menurut Permenaker No. 13 Tahun 2012}

Permenaker mengatur kriteria komponen dan pelaksanaan tahapan pencapaian kebutuhan hidup layak sebagaimana tercantum dalam pasal 88 ayat (1) UU Ketenagakerjaan. Dalam peraturan ini dijelaskan bahwa yang dimaksud dengan kebutuhan hidup layak (KHL) ialah standar kebutuhan yang harus dipenuhi oleh seorang pekerja lajang untuk dapat hidup layak baik fisik, non fisik dan sosial untuk kebutuhan 1 bulan. Nilai masing-masing komponen dan jenis KHL diperoleh melalui survei harga yang dilakukan secara berkala oleh Dewan Pengupahan Provinsi atau Kabupaten/Kota yang selanjutnya disampaikan

25 Pasal 93 Ayat (1) UU Ketenagakerjaan

26 Pasal 3 UU Ketenagakerjaan

27 Abdul Khakim, Pengantar Hukum Ketenagakerjaan Indonesia Berdasarkan UU Nomor 13 Tahun 2003 (Bandung: Citra Aditya Bhakti, 2003), h. 6

28 Khoirul Hidayah, Optimalisasi Pengawasan Ketenagakerjaan di Kota Malang. Dejure. Volume ke-7, Nomor 2: 2015, h. 101-115. 
kepada Gubernur secara berkala. Permenaker menjelaskan bahwa penetapan upah minimum didasarkan pada KHL dan dengan memperhatikan produktivitas dan pertumbuhan ekonomi. Selain itu beberapa faktor yang menjadi pertimbangan adalah ${ }^{29}$ :

1. Nilai KHL yang diperoleh ditetapkan dari hasil survey

2. Produktivitas makro yang merupakan hasil perbandingan antara jumlah Produk Domestik Regional Bruto (PDRB) dengan jumlah tenaga kerja pada periode yang sama

3. Pertumbuhan ekonomi merupakan pertumbuhan nilai PDRB

4. Kondisi pasar kerja, yang merupakan perbandingan jumlah kesempatan kerja dengan jumlah pencari kerja di daerah tertentu pada periode yang sama

5. Kondisi usaha yang paling tidak mampu (marginal) yang ditunjukkan oleh perkembangan keberadaan jumlah usaha marginal di daerah tertentu pada periode tertentu.

Upah minimum ini berlaku bagi pekerja dengan masa kerja kurang dari 1 (satu) tahun. Komponen KHL dalam Permenaker meliputi 7 (tujuh) unsur yaitu makanan dan minuman, sandang, perumahan, pendidikan, kesehatan, transportasi, serta rekreasi dan tabungan. Dalam 7 (tujuh) unsur itu mengandung 45 komponen, contoh unsur makanan dan minuman seperti beras, susu, minyak, sayur, buah, teh dan bumbu-bumbuan. ${ }^{30}$

\section{Konsep Maslahah Murslah Najmuddin Ath-Thufi}

Menurut pemikiran Najmuddin Ath-Tufi intisari dari keseluruhan ajaran Islam yang terkandung dalam nash ialah kemaslahatan bagi manusia secara universal. Menurut Ath-Thufi seluruh macam bentuk kemaslahatan disyari'atkan dan wujud maslahah itu tidak perlu memperoleh konfirmasi dari nash. Pemikiran Ath-Thufi yang tidak sejalan dengan para ulama semasanya menyebabkan ia ketinggalan, tetapi substansi pemikirannya kemudian mendapat perhatian para pakar sesudahnya. ${ }^{31}$ Ath-Thufi telah menulis syarah empat puluh hadis yang dikumpulkan oleh Imam Nawawi dalam kitab Syarh al-Arba'in an-Nawawiyyah. Ketika telah sampai hadis ketiga puluh dua yaitu:

Ath-Thufi merasa kesulitan dalam mensyarahnya, kemudian beliau mendapatkan inspirasi terhadap dalil syar'i yang berkaitan dengan hukum dan

29 Pasal 6 Ayat (2) Permenaker Nomor 13 Tahun 2012

30 Lampiran 1 Permenaker Nomor 17 Tahun 2005

31 Khairunnas Rajab dan Efrinaldi, Rekonstruksi Teori Maslahah dalam Kajian Pembaharuan Perundangan Islam: Analisis Terhadap Pemikiran Najmuddin Ath-Thufi.Jurnal Syariah. Volume ke- 3: 2009. 
posisi pemeliharaan maslahat dalam hadits ini. Beliau dalam mensyarah hadis ini memiliki pandangan yang berbeda dengan ulama terdahulu. Bagi Ath-Thufi, tujuan syariat adalah kemaslahatan sehingga segala bentuk maslahat harus dicapai tanpa merincinya.

Beberapa inti dari pemikiran yang digunakan At-Thufi dalam teori maslahah mursalahnya yang dipandang sangat berbeda dari para ulama lainnya ialah sebagai berikut: ${ }^{32}$

(1) Akal bebas menentukan kemashlahatan dan kemafsadatan, khususnya dalam bidang muâmalah dan adat. Dasar ini membawa implikasi bahwa untuk menentukan sesuatu itu mashlahah atau bukan, cukup digunakan nalar manusia tanpa harus didukung oleh nash.

(2) Mashlahah merupakan dalil mandiri dalam menetapkan hukum. Oleh sebab itu untuk kehujjahan mashlahah tidak diperlukan dalil pendukung karena mashlahah itu didasarkan pada pendapat akal semata.

(3) Ruang lingkup mashlahah terbatas pada persoalan muâmalah duniawi dan adat kebiasaan. Muâmalah dimaksudkan untuk memberikan kemashlahatan dan manfaat kepada manusia.

(4) Mashlahah merupakan dalil syara' yang terkuat. Mashlahah bukan hanya merupakan hujjah semata ketika tidak terdapat dalam nash dan ijma' tapi juga harus didahulukan atas nash dan ijma' di saat terjadi pertentangan antara keduanya.

\section{Pembahasan}

Berdasarkan prinsip hukum ketenagakerjaan yang terdapat di dalam UU Ketenagakerjaan, maka beberapa ketentuan pengupahan dalam PP No. 78 Tahun 2015 yang mengandung prinsip-prinsip tersebut, di antaranya ialah:

1. Prinsip Demokrasi

Prinsip demokrasi yang terkandung dalam PP, diwujudkan dalam beberapa pasal, yaitu:

(a) Pasal 1 angka 10 yang menjelaskan tentang adanya serikat pekerja. Dalam pasal ini terlihat bahwa pekerja diberikan hak membentuk sebuah organisasi sebagai wadah bagi mereka untuk bermusyawarah dan mengeluarkan pendapat mereka tentang ketentuan dalam dunia kerja pada instansi yang mereka tempati.

(b) Pasal 15 ayat (2) yang menyatakan bahwa pekerja dan pengusaha memiliki hak yang sama untuk melakukan musyawarah untuk mufakat dalam membuat sebuah kesepakatan. Kesepakan yang dimaksud dalam 32 Mushtafa Zaid, al-Mashlahah fî al-Tasyrî̀ al-Islamî wa Najmuddin al-Thufî (Mesir: Daar al-Fikr alArabi, 1964), h. 127 
pasal ini adalah kesepakatan dalam menetapkan besarnya upah pekerja berdasarkan satuan hasil yang diperoleh dari hasil pekerjaan yang telah disepakati oleh keduanya.

(c) Pasal 32

Pengaturan pelaksanaan ketentuan sebagaimana dimaksud dalam pasal 24 sampai dengan pasal 31 ditetapkan dalam perjanjian kerja, peraturan perusahaan atau perjanjian kerja bersama.

Berdasarkan pasal tersebut, terlihat jelas bahwa dalam menetapkan upah bagi pekerja yang berhalangan sebagaimana diatur dalam pasal 24 ayat (2), maka besarnya upah bisa pula ditetapkan dalam perjanjian kerja bersama yang di dalamnya mengikutsertakan pekerja dalam berpendapat.

2. Prinsip Perlindungan Tenaga Kerja Sesuai Harkat dan Martabat Kemanusiaan

Prinsip demokrasi yang terkandung dalam PP, diwujudkan dalam beberapa pasal, yaitu:

(a) Pasal 3 ayat (2), PP Nomor 78 Tahun 2015 juga telah memberikan pengaturan terkait hak bagi pekerja untuk istirahat. Selanjutnya yang dimaksud dengan hak dasar pekerja untuk mendapat hak waktu istirahat diatur pada pasal yang lain.

Hak waktu istirahat pekerja ialah sebagai berikut ${ }^{33}$ :

(1) hak istirahat mingguan;

(2) cuti tahunan;

(3) istirahat panjang;

(4) cuti sebelum dan sesudah melahirkan; atau

(5) cuti keguguran kandungan

(b) Pasal 6 ayat 1, Pasal ini menyatakan bahwa perlindungan tenaga kerja sesuai martabat juga berupa pemberian tunjangan hari raya keagamaan bagi masing-masing pekerja. Pemberian tunjangan hari raya dianggap sebagai perlindungan sesuai martabat kemanusiaan karena pekerja bukanlah hanya berperan sebagai pekerja, namun juga sebagai manusia berkeyakinan (agama) yang harus dihormati.

(c) Pasal 33. Upah kerja lembur sebagaimana dimaksud dalam pasal 3 ayat (2) huruf $\mathrm{b}$ wajib dibayar oleh pengusaha yang mempekerjakan pekerja/buruh melebihi waktu kerja atau pada istirahat mingguan atau dipekerjakan pada hari libur resmi sebagai kompensasi kepada pekerja/ buruh yang bersangkutan sesuai dengan ketentuan peraturan perundangundangan.

33 Pasal 24 Ayat (5) PP Nomor 78 Tahun 2015 
Perlindungan tenaga kerja juga berlaku bagi para pekerja yang melakukan kerja lembur. Hal ini dimaksudkan agar pengusaha memberikan hak yang sesuai dengan kinerja pekerja. Apabila pekerja dituntut untuk melakukan pekerjaan dengan jam kerja lembur, maka dengan pertimbangan martabat sebagai manusia pekerja juga harus mendapatkan upah kerja lembur. Karena mereka telah merelakan waktu istiahat mereka untuk melaksanakan pekerjaan tersebut, sehingga sudah seharusnya upah yang mereka dapat juga merupakan upah keja lembur.

(d) Pasal 35. Upah untuk pembayaran pesangon sebagaimana dimaksud dalam pasal 34 ayat (1) dan ayat (2) diberikan dengan ketentuan:

(1) Dalam hal penghasilan pekerja/buruh dibayarkan atas dasar perhitungan harian, maka penghasilan sebulan adalah sama dengan 30 (tiga puluh) kali penghasilan sehari;

(2) Dalam hal upah pekerja/buruh dibayarkan atas dasar perhitungan satuan hasil, potongan/borongan atau komisi, penghasilan sehari adalah sama dengan pendapatan rata-rata per hari selama 12 (dua belas) bulan terakhir, dengan ketentuan tidak boleh kurang dari ketentuan upah minimum provinsi atau kabupaten/kota; atau

(3) Dalam hal pekerjaan tergantung pada keadaan cuaca dan upahnya didasarkan pada upah borongan, maka perhitungan upah sebulan dihitung dari upah rata-rata 12 (dua belas) bulan terakhir.

Pengaturan terkait adanya perlindungan tenaga kerja berupa pemberian uang pesangon merupakan bentuk perlindungan martabat pekerja.Karena bagi para peerja yang telah pensiun, mereka kesulitan untuk mendapatkan pekerjaan lagi.Dengan pertimbangan martabat dan kemanusiaan, maka para pekerja juga diberikan hak untuk mendapatkan uang pesangon dari instansi tempat mereka bekerja.

Perlindungan tenaga kerja sesuai martabat dan kehormatan kemanusiaan tidak hanya berupa kesejahteraan tenaga kerja saja, namun juga berupa pembangunan nasional yang bertujuan untuk meningkatkan produktivitas kerja. Produktivitas sendiri tidak hanya berarti ratio antara output dan input, namun juga berkaitan dengan aspek persaingan. Meningkatkan produktivitas tenaga kerja dapat dilakukan dengan meningkatkan hubungan industrial, sehingga apabila hubungan antara pekerja dengan pengusaha bersifat harmonis, maka berdampak pada produktivitas para pekerja dan akhirnya juga berimbas kepada peningkatan produktivitas perusahaan.Sehingga pembangunan nasional yang berupaya meningkatkan 
produktivitas dan daya saing dapat terwujud. ${ }^{34}$

Prinsip pembangunan nasional berupa peningkatan produktivitas dan daya saing perusahaan dapat ditemukan dalam pasal 23 ayat (1) yang menyatakan bahwa "peninjauan upah minimum menggunakan pertimbangan produktivitas dan pertumbuhan ekonomi dengan melihat kemampuan perusahaan". Penetapan upah minimum sebagaimana dimaksud dalam Pasal 43 ayat (1) dihitung dengan menggunakan formula perhitungan upah minimum. ${ }^{35}$ Formula perhitungan upah minimum sebagaimana dimaksud pada ayat (1) sebagai berikut ${ }^{36}$ :

$\mathrm{UMn}=\mathrm{UMt}+\{\mathrm{UMt} \mathrm{x}($ Inflasit $+\% \Delta \mathrm{PDBt})\}$

Dengan keterangan bahwa:

UMn : Upah minimum yang akan ditetapkan

UMt : Upah minimum tahun berjalan

Inflasit : Inflasi yang dihitung dari September tahun lalu sampai September tahun berjalan

$\triangle \mathrm{PDBt}$ : Pertumbuhan Produk Domestik Bruto yang dihitung dari pertumbuhan Produk Domestik Bruto yang mencakup periode kwartal III dan IV tahun sebelumnya dan periode kwartal I dan II tahun berjalan. ${ }^{37}$

Pasal ini sesuai dengan ketentuan peninjauan upah dalam UU Ketenagakerjaan. UU menyatakan bahwa peninjauan upah dilakukan dengan pertimbangan kemampuan perusahaan. Pasal 44 ayat (2) dalam PP menggunakan unsur PDBt sebagai bentuk kemampuan perusahaan. Sehingga dengan adanya formulasi yang tetap dan jelas, perusahaan mampu meninjau upah pekerja agar tetap sesuai kemampuan finansial perusahaan, hal ini secara tidak langsung telah memberikan perlindungan kepada upah pekerja sesuai martabat kemanusiaan. Karena dengan formulasi upah yang jelas, maka telah berdampak pada perlindungan upah pekerja yang jelas pula. Bentuk prinsip ini dalam PP Nomor 78 Tahun 2015 dinyatakan dalam kebijakan pengupahan. Kebijakan pengupahan diarahkan untuk pencapaian penghasilan yang memenuhi penghidupan yang layak bagi pekerja/buruh. Pasal 43 Ayat (1) PP Nomor 78 Tahun 2015 "Penetapan upah minimum sebagaimana dimaksud dalam pasal 41 dilakukan setiap tahun berdasarkan kebutuhan hidup Layak dan dengan memperhatikan produktivitas dan pertumbuhan ekonomi". ${ }^{38}$

34 Adrian Sutedi, Hukum..., h. 36

35 Pasal 44 Ayat (1) PP Nomor 78 Tahun 2015

36 Pasal 44 Ayat (2) PP Nomor 78 Tahun 2015

37 Penjelasan Pasal 44 Ayat (2) PP Nomor 78 Tahun 2015

38 Pasal 43 Ayat (1) PP Nomor 78 Tahun 2015 
Prinsip perlindungan tenaga kerja semakin terlihat dengan adanya penetapan upah minimum yang dilakukan gubernur didasarkan pada kebutuhan hidup layak yang dilakukan setiap tahun. Pada pasal 43 ayat (3) dan ayat (4) disebutkan bahwa kebutuhan hidup layak atau KHL memiliki beberapa komponen, dimana tiap komponen tersebut mengandung beberapa jenis kebutuhan hidup pekerja. Penggunaan KHL sebagai dasar penetapan upah minimum merupakan bentuk prinsip perlindungan tenaga kerja yang telah sesuai dengan harkat dan martabatnya.

2. Prinsip Non Diskriminasi

Pasal 43 Ayat (1) PP Nomor 78 Tahun 2015 menjelaskan bahwa "Setiap tenaga kerja memiliki kesempatan yang sama tanpa diskriminasi untuk memperoleh pekerjaan". ${ }^{39}$ Pengertian dari prinsip non diskriminasi sendiri dalam penjelasan pasal 5 UU Ketenagakerjaan dijelaskan bahwa setiap tenaga kerja mempunyai hak dan kesempatan yang sama untuk memperoleh pekerjaan dan penghidupan yang layak tanpa membedakan jenis kelamin, suku, ras, agama, dan aliran politik sesuai dengan minat dan kemampuan tenaga kerja yang bersangkutan, termasuk perlakuan yang sama terhadap para penyandang cacat.

Pasal di atas merupakan bentuk sikap non diskriminasi yang diberikan pemerintah kepada warga negara bahwa tiap warga negara memiliki hak yang sama tanpa diskriminasi (dibeda-bedakan) untuk mendapatkan pekerjaan yang layak, sebagaimana yang diatur dalam pasal 5 UU Ketenagakerjaan bahwa "setiap pekerja/buruh berhak memperoleh perlakuan yang sama tanpa diskriminasi dari pengusaba. ${ }^{40}$

PP Nomor 78 Tahun 2015 lahir untuk memberikan pedoman pengupahan yang baru bagi pelaku hubungan industrial agar tidak terjadi diskriminasi antar pihak. Sehingga wujud prinsip penjaminan hak dasar dan kesamaan kesempatan adalah berupa pemberian dan perlindungan upah yanglayak. "Setiappekerja/buruh berhak memperoleh upah yang sama untuk pekerjaan yang sama nilainya".41

Pasal dalam PP Nomor 78 Tahun 2015 yang mencerminkan adanya prinsip non dikriminasi ialah pasal 11. Pada pasal ini dijelaskan bahwa setiap pekerja/ buruh memiliki hak secara normatif dan mutlak untuk memperoleh upah yang sama terhadap pelayanan atau pekerjaan yang sama derajatnya. Pasal ini memiliki prinsip non diskriminatif sebagai representatif dalam mewujudkan pembangunan nasional.

\section{Prinsip No Work No Pay}

Prinsip ini berarti bahwa tiada pekerjaan, maka tiada upah. Dalam UU Ketenagakerjaan dijelaskan bahwa terdapat beberapa pengecualian terhadap

39 Pasal 5 UU Ketenagakerjaan

40 Pasal 6 UU Ketenagakerjaan

41 Pasal 11 PP Nomor 78 Tahun 2015 
pekerja yang tidak melakukan pekerjaannya sebagaimana dinyatakan dalam pasal 93 ayat (2) UU Ketenagakerjaan. Demikian pula dengan PP Nomor 78 Tahun 2015, di dalamnya juga mengandung pasal yang menjelaskan bahwa pekerja tidak mendapatkan upah apabila tidak melakukan pekerjaan mereka. Upah tidak dibayar apabila pekerja/buruh tidak masuk kerja dan/atau tidak melakukan pekerjaan. ${ }^{42}$

\section{Prinsip Keterpaduan}

Prinsip keterpaduan berarti setiap daerah-daerah di Indonesia diberikan hak untuk mengatur urusan rumah tangganya sendiri terkait hukum ketenagakerjaan. Meskipun demikian, segala peraturan dan ketentuan yang digunakan daerah dalam mengurus rumah tangganya tetap berasal dari pusat. Prinsip ini terkandung dalam bunyi pasal berikut ini "Dalam hal telah dilakukan peninjauan kebutuhan hidup layak sebagaimana dimaksud dalam pasal 43 ayat (5), gubernur menetapkan upah minimum kabupaten/kota dengan memperhatikan rekomendasi bupati/walikota serta saran dan pertimbangan dewan pengupahan provinsi" ${ }^{43}$

Dari pasal di atas, terlihat bahwa terdapat prinsip keterpaduan dan koordinasi antara pihak pusat dan daerah dalam melakukan peninjauan KHL. Meskipun pada akhirnya yang menetapkan adalah gubernur, namun pada prosesnya gubernur tetap memperhatikan rekomendasi dari bupati/walikota dan saran serta pertimbangan dewan pengupahan provinsi.

\section{Perubahan Ketentuan Pengupahan dalam PP Nomor 78 Tahun 2015}

Pasal dalam PP Nomor 78 Tahun 2015 yang dianggap oleh para pekerja sebagai pasal yang lebih mendukung para pengusaha dan akhirnya menimbulkan para pekerja melakukan demo ialah pasal 44 ayat (2) mengenai adanya formulasi upah yang menggunakan pertimbangan tingkat inflasi. Selain itu juga ada salah satu pasal dalam PP yang merupakan sebab adanya demo para buruh, pasal tersebut berbunyi "komponen sebagaimana dimaksud pada ayat (3) dan jenis kebutuhan hidup sebagaimana dimaksud pada ayat (4) ditinjau dalam jangka waktu 5 (lima) tabun".44

Pasal ini merupakan pasal yang menjadi permasalahan para pekerja, karena peninjauan komponen dan jenis kebutuhan masyarakat yang hanya dilakukan selama 5 tahun sekali. Sedangkan harga kebutuhan bersifat relatif yang bisa mengalami

42 Pasal 24 Ayat (1) PP Nomor 78 Tahun 2015

43 Pasal 47 Ayat (2) PP Nomor 78 Tahun 2015

44 Pasal 43 Ayat (5) PP Nomor 78 Tahun 2015 
kenaikan harga atau penurunan harga. Apabila peninjauan komponen dan jenis kebutuhan hidup hanya dilakukan sekali dalam jangka waktu 5 (lima) tahun, maka telah merugikan masyarakat apabila upah yang mereka dapatkan tidak sesuai dengan harga kebutuhan hidup layak. Tingkat harga kebutuhan hidup yang sifatnya tidak stabil dan tetap, telah mengakibatkan perekonomian para pekerja menurun ketika harga kebutuhan mengalami kenaikan.Ketika harga barang masih bersifat relatif, maka seharusnya ketentuan besarnya upah pekerja juga relatif dan disesuaikan dengan tingkat harga kebutuhan hidup layak manusia.

Bunyi pasal di atas apabila diamati sekilas memang tidak sesuai dengan prinsip perlindungan tenaga kerja. Karena apabila peninjauan terkait komponen jenis kebutuhan hidup manusia hanya dilakukan sekali dalam jangka waktu 5 (lima) tahun, maka berdampak buruk pada pertumbuhan ekonomi pekerja. Namun demikian, menurut peneliti pasal ini sebenarnya telah sesuai dengan prinsip perlindungan tenaga kerja, hanya saja bentuk perlindungan tidak lagi diwujudkan dengan melakukan peninjauan komponen KHL tiap tahun namun dengan diberlakukannya formula upah pekerja yang tetap.

Sebelumnya telah diatur pula pada Pasal 4 Ayat (7) Kepmenaker Nomor 226 Tahun 2000 sebagai pelaksanaan PP Nomor 8 Tahun 1981 bahwa peninjauan upah dilakukan pemerintah selama kurun waktu 1 (satu) tahun sekali. Dengan dasar inilah, terlihat bahwa antara PP Nomor 78 Tahun 2015 dengan PP Nomor 8 Tahun 1981 memiliki perbedaan mengenai pelaksanaan peninjauan upah. Selain hal tersebut, beberapa perbedaan lain antara keduanya ialah sebagai berikut:

Tabel 1. Perubahan Ketentuan Pengupahan

\begin{tabular}{|c|c|c|c|}
\hline No. & Unsur & Ketentuan lama & Ketentuan baru \\
\hline 1. & $\begin{array}{l}\text { Pertimbangan } \\
\text { dalam } \\
\text { peninjauan } \\
\text { upah }\end{array}$ & $\begin{array}{l}\text { Penyesuaian harga } \\
\text { KHL dan/atau } \\
\text { peningkatan produktivitas } \\
\text { kerja dengan } \\
\text { mempertimbangkan } \\
\text { kemampuan perusahaan. }\end{array}$ & $\begin{array}{l}\text { Peningkatan kesejahteraan } \\
\text { pekerja tanpa mengabaikan } \\
\text { peningkatan produktivitas, } \\
\text { kemajuan perusahaan dan } \\
\text { perkembangan ekonomi. }\end{array}$ \\
\hline 2. & $\begin{array}{l}\text { Peninjauan } \\
\text { upah }\end{array}$ & $\begin{array}{l}\text { Ditinjau dalam jangka } \\
\text { waktu } 5 \text { (lima) tahun } \\
\text { sekali. }\end{array}$ & $\begin{array}{l}\text { Ditinjau dalam jangka waktu } \\
1 \text { (satu) tahun sekali. }\end{array}$ \\
\hline 3. & $\begin{array}{l}\text { Penetapan } \\
\text { upah } \\
\text { minimum }\end{array}$ & $\begin{array}{l}\text { Ada formula upah, yaitu } \\
\text { UMn }=\text { Umt }+\{\text { Umt x } \\
(\text { Inflasit }+\% \Delta \text { PDBt })\}\end{array}$ & Tidak ada formula upah \\
\hline
\end{tabular}




\begin{tabular}{cll}
\hline 4. Pertimbangan & Angka inflasi dan & Kebutuhan, indeks harga \\
formula upah & Pertumbuhan Produk & konsumen, kemampuan \\
& Domestik Bruto (PDBt). & perusahaan, upah pada \\
& & umumnya, kondisi pasar \\
& kerja, tingkat perkembangan \\
& ekonomi.
\end{tabular}

Sumber: Data diolah dari Kepmenaker Nomor 226 Tahun 2000 sebagai pelaksanaan PP Nomor 8 Tahun 1981 tentang Perlindungan Upah dan PP Nomor 78 Tahun 2015 tentang Pengupahan.

\section{Perpektif Maslahah Mursalah Ath-Thufi terhadap Perubahan Ketentuan Pengupahan}

Independensi rasio dalam menemukan maslahah dalam hal ini ialah pembuatan PP Nomor 78 Tahun 2015. Pemerintah melakukan rasio antara manfaat dan kesulitan yang telah dialami pihak dalam hubungan kerja apabila PP Nomor 78 Tahun 2015 ini tidak ada. PP Nomor 78 Tahun 2015 yang dianggap bertentangan dengan prinsip hukum ketenagakerjaan dalam UU Ketenagakerjaan sebagai peraturan yang lebih tinggi sangatlah salah. Karena ketentuan pengupahan ini sesungguhnya tidak bertentangan, hanya saja memberikan formulasi baru terkait kebutuhan hidup layak.

Ketentuan peninjauan komponen dalam KHL yang dilakukan sekali dalam jangka waktu 5 (lima) tahun dan dibentuknya formulasi upah, hanyalah bertujuan untuk melindungi para pekerja apabila perusahaan mengalami pailit atau PHK besar-besaran. Karena apabila PHK dilakukan perusahaan, para pekerja tetap mendapatkan upah mereka berdasarkan formulasi upah yang telah ada. Selain itu juga untuk memudahkan para pengusaha dan pemerintah dalam menetapkan upah pekerja. Apabila penetapan upah dilakukan tiap tahun, maka bisa menyulitkan pengusaha dan pemerintah.

Berdasarkan teori maslahah mursalah Ath-Thufi, PP Nomor 78 Tahun 2015 ini dibolehkan dan dianggap benar meskipun terdapat 1 (satu) pasal yang tidak sesuai dengan salah satu prinsip ketenagakerjaan, yaitu prinsip perlindungan tenaga kerja sesuai harkat dan martabat kemanusiaan. Karena tujuan dilakukannya peninjauan selama 5 (lima) tahun adalah untuk mewujudkan kemaslahatan antara pekerja, pengusaha serta pemerintah, dan untuk menghindari kesulitan bagi ketiga pihak tersebut.

Pemikiran terakhir Ath-Thufi ini menjelaskan bahwa sesungguhnya bentuk maslahah mursalah bukanlah bertujuan untuk menafikan sumber hukum yang 
ada di atasnya. Namun bertujuan untuk menetralisir keumuman sumber hukum tersebut (nash). Apabila dikaitkan dengan PP Nomor 78 Tahun 2015, maka tujuan dibuatnya PP adalah untuk menetralisir keumuman ketentuan pengupahan dalam UU Ketenagakerjaan. Bahwa untuk melaksanakan ketentuan pasal 97 Undangundang Nomor 13 Tahun 2003 tentang Ketenagakerjaan, perlu menetapkan peraturan pemerintah tentang pengupahan. ${ }^{45}$

Berdasarkan teori yang dicetuskan oleh Najmuddin Ath-Thufi di atas, maka regulasi Peraturan Pemerintah Nomor 78 Tahun 2015 ini sama sekali tidak menyebabkan dan tidak melahirkan diskriminasi antara pekerja dengan pengusaha. Hal ini dikarenakan bahwa tujuan dari pembentukan PP ialah untuk mencapai KHL pekerja dan mewujudkan kesejahteraan antara sesamanya, yaitu pekerja, pengusaha dan pemerintah.

\section{Simpulan}

Berdasarkan pembahasan, dapat diambil kesimpulan bahwa seluruh pasal dalam PP Nomor 78 Tahun 2015 telah sesuai dengan prinsip hukum ketenagakerjaan. Permasalahan yang muncul pada pasal 43 ayat (5) tidak menyimpang prinsip hukum ketenagakerjaan, karena penetapan upah sudah dibuat berdasarkan formula upah pada pasal 44 ayat (2). Maslahah Mursalah Ath-Thufi menyatakan bahwa perubahan tersebut merupakan manifestasi kemaslahatan umum. Kemaslahatan yang muncul ialah meminimalisir PHK, memberikan perlindungan upah pekerja melalui formula upah tetap, dan memudahkan pemerintah melakukan peninjauan upah minimum.

Peninjauan komponen KHL yang dilakukan 5 (lima) tahun sekali masih bersifat memberatkan pekerja, karena jangka tersebut terbilang terlalu lama dan berakibat pada angka inflasi. Sebaiknya peninjauan bisa dilakukan 3 (tiga) tahun sekali, sehingga peninjauan tersebut tidak terlalu lama dan terlalu cepat. Tahap dalam meregulasi setiap peraturan perundang-undangan harus memperhatikan prinsip dasarnya, sehingga tidak terjadi kesenjangan di masyarakat. Karena prinsip merupakan sebuah landasan, dan setiap peraturan yang baik harus memiliki landasan agar jelas dan tepat. Sehingga para pekerja mampu memahami bahwa regulasi PP bertujuan menciptakan kemaslahatan umum berdasarkan prinsip keadilan di antara semua pihak.

45 PP Nomor 78 Tahun 2015 Bagian Menimbang 


\section{Daftar Pustaka}

Ali, Zainuddin. Metode Penelitian Hukum. Jakarta: Sinar Grafika.

Ibrahim, Johnny. Teori dan Metodologi Penelitian Hukum Normatif. Malang: Bayumedia Publishing, 2007.

Khakim, Abdul. Pengantar Hukum Ketenagakerjaan Indonesia Berdasarkan UU Nomor 13 Tahun 2003.Bandung: Citra Aditya Bhakti, 2003.

Maktabah Syamilah, Sunan Ibnu Majah Bab Upah-mengupah, Juz 2.

Nasution, Bahder Johan. Metode Penelitian Hukum. Bandung: CV Mandar Maju, 2008.

Rahayu, Devi. Hukum Ketenagakerjaan Teori dan Studi Kasus. Yogyakarta: New Elmatera, 2011.

Rahman, Abdul Al-Jaiziri.Al-Figh 'Al Madzhib Al-Arba’ah Juz 3. Beirut: Daar AlKutub Al-Ilmiyah, 2003.

Ridwan. Fiqih Perburuan. Yogyakarta: Centra Grafindo, 2007.

Sahrani, Sohari dan Ru'fah Abdullah. Fikih Muamalah. Bogor: Ghalia Indonesia, 2011.

Soepomo, Imam. Pengantar Hukum Perburuban. Jakarta: Djambatan, 1990.

Suhendi, Hendi. Fiqih Muamalah. Jakarta: Rajawali Press, 2010.

Sutedi, Adrian. Hukum Perburuan. Jakarta: Sinar Grafika, 2009.

Syafe'i, Rachmat. Fiqih Muamalah. Bandung: Pustaka Setia, 2001.

Syarifuddin, Amir. Ushul Fiqh Jilid 2. Jakarta: Prenada Media Group, 2011.

Zaid, Mushtafa.al-Mashlahah $f i$ al-Tasyri al-Islami wa Najmuddin al-Thufi, cet ke-2. Mesir: Daar al-Fikr al-Arabi, 1964.

Perundang-Undangan

Undang-undang Dasar Negara Republik Indonesia Tahun 1945

Undang-Undang Nomor 13 Tahun 2003 tentang Ketenagakerjaan, (Lembaran Negara Republik Indonesia Tahun 2003 Nomor 39; Tambahan Lembaran 
Negara Republik Indonesia Nomor 4279).

Peraturan Pemerintah Nomor 78 Tahun 2015 tentang Pengupahan, (Lembaran

Negara Republik Indonesia Tahun 2015 Nomor 237; Tambahan Lembaran

Negara Republik Indonesia Nomor 5747).

Peraturan Menteri Tenaga Kerja dan Transmigrasi Nomor 13 Tahun 2012 tentang Komponen dan Pelaksanaan Tahapan Pencapaian Kebutuhan Hidup Layak, (Berita Negara Republik Indonesia Tahun 2012 Nomor 707).

Peraturan Menteri Tenaga Kerja dan Transmigrasi Nomor PER-17/MEN/

VIII/2005 tentang Komponen dan Pelaksanaan Tahapan Pencapaian Kebutuhan Hidup Layak.

\section{Kamus dan Jurnal}

Departemen Pendidikan Nasional, Kamus Besar Bahasa Indonesia. Jakarta: Pusat Bahasa, 2008.

Hidayah, Khoirul. Optimalisasi Pengawasan Ketenagakerjaan di Kota Malang.

Dejure. Volume ke-7 Nomor 2: 2015.

Khairunnas Rajab dan Efrinaldi, Rekonstruksi Teori Maslahah dalam Kajian

Pembaharuan Perundangan Islam: Analisis Terhadap Pemikiran Najmuddin Ath-Thufi. Jurnal Syariah. Volume ke-3: 2009.

\section{Website}

Http://news.liputan6.com/

Http://www.kompasiana.com/

Http://news.detik.com/ 